\title{
THE APPLICATION OF BEHAVIOURAL FINANCE TO ENHANCE VOLUNTARY RETIREMENT SAVINGS - ARE THE SOLUTIONS UNIVERSAL AROUND THE WORLD?
}

\begin{abstract}
Behavioural finance is a promising solution to enhance voluntary retirement savings (VRS) and is gaining recognition around the world. Despite this, there may be some limitations to the transferability of its applications. This paper summarizes the key findings relevant to long-term savings and then analyses these aforementioned limitations, by first pointing to some methodological assumptions made, and then looking at the potential set of variables impacting the applications' transferability.
\end{abstract}

Key words: behavioural finance, voluntary retirement savings, pension systems, multi-pillar pension systems.

\section{INTRODUCTION}

The purpose of pension systems is to provide its participants with a nonearning means of subsistence for the period of old age at an appropriate level [Szumlicz 2005: 243]. Taking into account the low expected replacement rate from the base PAYG system [OECD 2012; OECD 2011; Antolin 2008: 10], it seems reasonable to conclude that the introduction and use of voluntary retirement savings vehicles (VRS), in some format, is indispensable [EU Commission 2012: 14; OECD 2007; EUC 2010; PIU 2010; Antolin and Whitehouse 2009].

The primary argument for VRS is undoubtedly that it allows for an individually selected time and value of deposits. People may have other priorities at a given point in time than retirement, for example the purchase of a house or apartment, or even a family event, such as a wedding. If the premiums were obligatorily increased, it could cause more damage, if for example it were to be made at the expense of the education of children [Antolin and Whitehouse 2009: 22]. This paper assumes its definition of the VRS vehicles according to the OECD [Mikulec 2012]: VRS are private, voluntary, occupational or personal pension schemes.

\footnotetext{
${ }^{*}$ Warsaw School of Economics, Department of Social Insurance.
} 
This paper will not undertake a discussion concerning the issue of the evaluation of VRS in relation to other methods, such as raising social security rates or the use of capital funds in the public part of the pension system. Rather this paper focuses on retirement saving decisions, their related consequences and factors influencing those decisions from an international perspective. The question is, what are the factors determining participation in and adequacy of savings in the VRS vehicles? In the following section, a literature review will be presented, documenting the theoretical adequacy of behavioural interventions and pre-existing evidence of their application to enhance voluntary retirement savings. The next section will provide some analysis seeking to answer the question of whether behavioural techniques are independent variables or whether there is a group of factors that impacts their effectiveness and therefore renders the solution not necessarily globally universal.

\section{THE APPLICATION OF BEHAVIOURAL FINANCE IN PENSION SYSTEMS}

The application of VRS places the issue of transfer (to a large extent at least) of the responsibility for the adequacy of the level of future pension benefits onto the participants of the system. Such a move requires answers to questions regarding savings versus consumption choices. For this reason, there is a significant development of interest in the subject of behavioural finance $(B F)$, focused on intertemporal choices. Most studies were conducted in the USA, but there is a growing interest, most notably in the United Kingdom, but also in Denmark, Sweden, the Netherlands, among others [see: Lunn 2012; Hardcastle 2012; Tapia and Yermo 2007; Antolin et al 2012; Mitchell and Utkus 2004; Barr and Diamond 2008; Brunhart 2008; EIOPA 2013]. BF is becoming used in wider contexts, not just explicitly like in the US, New Zealand or the UK (all of them liberal, Anglo-Saxon social security regimes), but also implicitly; so there are solutions whose effectiveness can be explained in the light of behavioural finance (e.g. salary conversion in bAV betriebliche Altersvorsorge in Germany).

At the outset, it should be clarified that neither behavioural economics nor finance assume that man is irrational [see for example: Kahneman 2012; Shefrin and Thaler 1981; Thaler 1999 and many others]. Shefrin \& Thaler [1981] refer to the struggle between the farsighted planner with myopic doer, on the subject of deferring gratification, planning, etc. In accordance with the concept of Stanovitch and West (an extensive review of the literature concerning this concept can be found in: Evans [2003]), human cognition is based on a dual operating system (Systems 1 and 2). In this setting, at any given time, we can use ,auto-pilot”, i.e. heuristic System 1, which we use every day for simpler 
tasks, or a fully rational (but rather lazy) „controller” in System 2, which we save for more difficult tasks, and whose activation requires focus and attention. An adaptation of this concept is presented extensively in Kahneman [2012: 19-30]. Thinking and, as a consequence, human behaviour, is the result of an unbreakable hybrid of these two systems.

These issues seem to be best reflected in Richard Thaler's proposition: „quasi-rationality". Considered by many to be father of behavioural economics, Thaler [2000] introduces this concept, taking into account that people have good intentions, but because they have limited capacity to process information and control behaviour, they apply a number of heuristics and are subject to numerous effects and biases. This chapter discusses selected aspects of BF which are of the most significance in the author's humble opinion.

Behavioural finance and economics derive from the observation that neoclassical models simplify human behaviour, reducing it to one of a cool minded sage, who possesses all the relevant information and who is able to properly take into account all the variables, assesses the likelihood of their occurrence and appropriately measures their weight [Mitchell and Utkus 2004: 3]. This assumption is simply very difficult to verify through observation. The behavioural approach assumes a more realistic situation, that an economic agent must make decisions without access to full information, with limited cognitive abilities, and is subject to some biases in thinking and actions [Knoll 2010]. The decision-making process is impacted by self-control, emotions, and the architecture of choice. Taking into account these more realistic assumptions, BF provides valuable tools, enriching neo-classical theory.

The following paragraphs will present the body of research summarizing the impact of psychological inhibitors on participation in voluntary retirement savings vehicles.

\subsection{Risk aversion}

The precursors of behavioural economics, later Noble prize winner Daniel Kahneman and his close colleague Amos Tversky, began the use of psychology in economics in their article entitled: Prospect Theory: An Analysis of Decision under Risk [Kahneman and Tversky 1979). According to this theory, people perceive gains quite differently than losses (the ratio of profit to loss oscillates around 2-2.5: 1). Fear of risk, due to the fact that investments are not usually guaranteed, may lead to a reluctance to participate. This phenomenon can be explained by the endowment effect and certainty effect [Kahneman, Knetsch and Thaler 1991 and 2008]. We prefer a smaller but certain profit to a larger but uncertain one. People are also reluctant to risk what they have already accumulated. In the case of VRS, saving via bank deposits is „more reliable” because of the money illusion effect. A nominal profit, in the form of interest, is 
guaranteed, even though erosion caused by inflation causes the real value of savings to oscillate around the level of $100 \%$ of the initial value of deposit, if not actually drop. Neverthless, a significant decrease in value of bank deposits caused by crisis on stock exchange is virtually impossible, as is the case with investments on stock market. The most common solution to this problem is the provision of a guaranteed minimum rate of return or the incorporation of a lifecycle strategy, limiting the risk. These safety measures however, obviously decrease the likelihood of achieving otherwise potentially higher returns on investments.

\subsection{Cognitive limitations and intertemporal choices}

Due to a lack of understanding of certain difficult topics or merely for convenience, people use heuristics. Heuristics are mental shortcuts, educated guesses at more complex problems. Based on a single heuristic, there can be a number of identified biases and effects [Baddeley 2013]. In the case of retirement savings, the two most significant are: mental accounting and non-exponential discounting.

The basic premise of mental accounting [Thaler 1990, 1999] or mental accounts systems, is that people perceive differently current income (I), current assets $(A)$ and future income $(F)$. Mental accounts systems break with the principle of a full substitutability of the various forms of money [Bańbuła 2006].

The perception of time is also sometimes distorted by the cognitive limitations of the discounting function (Frederick, Loewenstein and O'Donoghue [2002] and Loewenstein, George and Thaler [1989]). Hyperbolic discounting and quasi hyperbolic discounting are both confirmed empirically [Baddeley 2013; Diamond and Koszegi 2003; Brunhart 2008]. The perceived value of future income is much less than in reality, as calculated using exponential discounting. Saving affects current income (I) most, but to some degree also current assets (A), because they are closest to the present, i.e. their discount factor is the highest. Since there is a tendency to delay taking adverse actions, it may lead to inertia or the status quo bias presented in the next paragraph.

\subsection{Motivation and self-control}

Shefrin and Thaler [1981] discuss the gap between intentions and actions. This discrepancy can be explained by the effect of inertia and procrastination as well cognitive dissonance. Inertia is nothing but the simplest action: a lack of action. People know they should save, but they do not know how to go about it, so they do nothing. Procrastination is deferring an action until "tomorrow". Tomorrow, one decides to do it, „tomorrow”, and so on. Construction and 
tangible incentives have little impact on this phenomenon. These effects have been explicitly used in the reconstruction of the pension system in the United Kingdom [Hardcastle 2012]. It was considered necessary to reform the system due to the decreasing participation in additional pension plans, despite the universality of the application of occupational pension plans and individual programs, as well as the generous tax breaks; where contributions are tax-exempt up to 50,000 pounds per year (fiscal year 2013/14), and the tax breaks range from $20 \%$ to $45 \%$ of gross salary, depending on the level of income [Greenwood 2012; Sieczkowski 2014]. The conclusion is that even this type of relief is not a sufficient condition to increase participation. The proposed solution is to use a framing effect; setting the architecture of choice to participation via auto-enrolment. This solution has already been widely used in New Zealand [Arkinstall 2008], the USA [Iwry and John 2009; Beshears et al. 2008] and since 2012 in the United Kingdom [Hardcastle 2012]. In auto-enrolment, the default option is participation in the scheme from which one needs to actively unsubscribe (opt out). Studies confirm higher participation rates in schemes of this kind than in those plans requiring active subscription [e.g. Mitchell and Utkus 2004; Madrian and Shea 2001].

It is not the only application of the framing effect. Depending on the presentation of the specific initial situation, there is a wide discrepancy in the choices taken by people. In this way, the remuneration strategies, which no longer think about retirement contributions in terms of yet another ,tax", but consider it in terms of an investment, an incentive to attract prospective employee, but above all a ,deferred compensation” (German: Engeltumwandlung) are gaining increasing recognition [Blaich 2010; Brunhart 2008]. The concept of deferred compensation is not new in the UK [see: Blake 2006 for example], but in countries like Poland is relatively innovative.

\section{LIMITATIONS OF TRANSFERABILITY AND UNIVERSALITY}

In the literature on the subject there are discussions about whether it is necessary to use additional incentives to save at all [e.g. Góra 2003]. People should be prescient enough to ponder and address their retirement. This statement is absolutely true, but it is a normative statement, and not a positive one [Barr and Diamond 2008: 174]. It is clear that we need to save, but we do not do it at a sufficiently high level.

The question is how to extend participation, and more importantly, the adequacy of contributions. Is behavioural finance the panacea to the problem? Most likely, the findings are universal on a personal level, but should the solutions take into consideration country specific differences? Is there a set of 
variables that affects the measurement of behavioural incentive effectiveness or are they universal?

This paper argues that the issues related to expanding participation in and the adequacy of supplementary pension schemes should be discussed in close connection with the basic issues relating to the structure of the pension system they were created in. It is therefore argued that the whole mosaic of activities, from „classic” tools, such as tax incentives matching contributions and subsidies, through „,behavioural” aspects, such as risk aversion to innovative solutions, e.g. Save More Tomorrow [Benartzi and Thaler 2004; Save More Tomorrow Act 2012] are required to be taken into account.

The following section will present a list of potential variables which impact and modify behavioural technique effectiveness.

\subsection{Wealth of citizens and the level of their disposable income}

One should take into account the difference between the actual scarcities of resources against rationalization, i.e. the tendency to explain behaviour without objective grounds to do so. People may say that they cannot afford to save in VRS, whereas in reality it is just an excuse. To verify whether the reason for insufficient savings is indeed rational, one should control for household savings rates, which is an objective indicator of ability to save. In order to check if people really cannot afford to save in VRS, one could check the savings rates (i.e. perhaps people just say they cannot save, but in fact they save on bank deposits etc.). Some people cannot afford VRS, for objective reasons, such as low levels of disposable income, or due to the burden of providing for aging parents or the education of their children. Some people have a risk aversion so high that they are inherently reluctant to invest in the stock market. However, there is also another group of people who are probably aware that they should save more for retirement, want to save and, in addition, declare this intention [Shefrin and Thaler 1981], but either postpone the decision ,till later" (procrastination) or, not knowing what to do, take no action at all (inertia, myopia).

It might be the case that people do not use VRS for rational reasons. The high level of charges and fees might limit the level of expected returns. Effectiveness might also be dependent on the use of guaranteed rates of returns and the range of bonuses and accelerators rewarding regular contributions.

\subsection{Social Policy Model}

BF applications can - and probably are - dependent on the specifics of the system, and therefore depend on the place where the research was conducted [Madrian 2012; Disney 2007; Knoll 2010]. The impact of behavioural incentives 
may be different in a system based on liberal social policy, which is where the responsibility for pension adequacy is shifted onto citizens; it may be different in a conservative environment, where contributions reflect previous earnings; and it may be even more distinct in a social democratic system, where the state provides for retirement, or at least that is the expectation of the society [Esping-Andersen 1990, 2002; Cousins 2005).

For instance, Benartzi and Thaler [2004] designed a VRS vehicle utilising behavioural finance called: Save More Tomorrow. This proposition not only addresses the issue of procrastination by automatic enrolment but also the issue of adequacy by the incorporation of legal commitments from its participants to increase contribution rates in line with future salary rises. The results are amazing, contribution rates grew almost fourfold, from 3.5 percent to 13.6 percent in less than four years [Benartzi and Thaler 2004; Mitchel and Utkus 2004]. However, this method is applicable in a very specific environment. It applies to 401(k) plans, requiring tax incentives for employers to establish occupational pension scheme, it requires an occupational pension plan in the first place as well as tax relief on employee contributions. Knoll [2010] reports that even in the US the majority of workers do not have access to 401(k) plans. In Poland, employers' contributions constitute a taxable event for employees and employee contributions are allowed only after tax.

\subsection{The design of the pension system}

There are some aspects that may have an impact on the propensity to save [Disney 2007; Brunhart 2008; Börsch-Supan 2004; Turner 1997; Crossley et al. 2012]. First of all, a high level of the base system replacement rates may discourage additional saving for rational reason - what is the incentive to do so? Equally, increased participation means increased labour costs for employers. The Beveridge systems are more likely to absorb these costs, where, for example, in the US, the federal social security rate is 13.5 percent, while in the UK it is 25.8 percent. But in Bismarckian systems, this type of solution may be inadequate. This is because the statutory, compulsory social security premiums are relatively high; Germany 39.45 percent, Poland ca. 33 percent. Since the mandatory social security rates are so high, why then, in addition, auto-save to VRS? What benefit is there for employers? It does require answering the question of what motivates employers to establish voluntary retirement plans in the first place. If they are considered an attractive motivator, where they constitute an important factor in creating a competitive advantage over competitors, then an occupational pension plan becomes an important component of the remuneration pay package. But if there is no market standard, and labour costs are already perceived of as high, then these plans will become just an additional burden. 
Secondly, mandatory and quasi mandatory alternatives may impact the utilisation of VRS. For example, Alessie, Rooij and Lusardi [2011: 3] give a very brief outline of the Dutch pension system, in which benefits from the basic pillar (AOW) pays $40 \%$ of the retirement pension and is solely dependent on the length of residence in the Netherlands. This is further increased by an occupational pillar of another $40 \%$, which is funded by employers, and, as an effect of collective agreements with trade unions, covers almost all workers (hence, the commonly used name quasi-mandatory scheme). In this environment, the voluntary pillar is of very little importance, due to the relatively high rate of replacement from the $1^{\text {st }}$ and the $2^{\text {nd }}$ pillar. There is no sense comparing the retirement savings behaviour of the Dutch with the Poles or the Irish, without taking account of those differences.

\subsection{Fiscal incentives}

Fiscal incentives have traditionally been highlighted as amongst the most important drivers of additional voluntary savings. There are three specific types of fiscal incentives; tax incentives as well as employer matching contributions and budgetary subsidies. Tax advantages and/or matching contributions compensate the perceived „loss" of income. However, although they may be a prerequisite for participation, they certainly do not constitute a sufficient condition. Although Madrian [2012: 19] reports that there is no evidence of effectiveness of matching contributions outside of the US, and that the effectiveness of matching contributions in the United States is minuscule, there is some evidence from Germany and New Zealand. The effects of Riester and KiwiSaver reforms respectively, [Pieńkowska-Kamieniecka and Ostrowska-Dankiewicz 2013] lead to the conclusion, however, that in both cases, these programmes encourage participation, but because the majority of the pay out is direct government subsidies, their macroeconomic effectiveness remains questionable. In relation to the second of the fiscal incentives, Holzmann and Hinz [2012] and Hinz [2008] show that the level of tax incentives is a bad predicator of participation in and adequacy of savings.

\subsection{Financial training, education and communication of results}

If there was a tangible method allowing everyone to understand the significance of VRS, or broader; the need to save for retirement, probably everyone would participate in some format. However, this would be an extremely expensive project, whose effectiveness is not guaranteed. This is the reason why the choice of structure should be constructed so as to minimize the effects of these deficiencies in financial education as far as possible. The 
findings of the current research on the application of behavioural finance are concentrated on "choice architecture" [Beshears et al 2006a, 2006b, 2008]; the creation of a structure that would facilitate decision making to increase the level of participation and adequacy using behavioural finance. The hallmark of an efficient system is a setting that allows the capture of all those undecided, myopic, deferring decisions along with encouraging (or at least not discouraging) those who have concerns, etc. before it is too late.

\subsection{Sales and Marketing}

Advertisements and direct selling can influence financial decisions. For example, in Poland, the reformers in 1999 assumed that PTE would compete through better results and lower fees. This did not happen. First of all, a significant proportion had not made an active choice, and so were drawn to Open Pension Funds (OFE). People were drawn to OFE from March 2000 to January 2014. There have been 27 draws, involving $2.7 \mathrm{~m}$ people. The highest number drawn was in January 2014, where almost 290 thousand people did not make any choice. The smallest number was in June 2000, with only 4.3k drawn. Secondly, people kept their funds, and changing behaviours were correlated with advertisement and sales expenditure instead. Chybalski [2009 and 2011], found no correlation with results, but a significant one with marketing and advertisement cost. Similarly, Stanko [2010] found a correlation of 0.41 with expenditure on marketing and advertisement. This casts a shadow over the assumption of a complete rationality of choice.

\section{FURTHER RESEARCH AND CONCLUSIONS}

Although $\mathrm{BF}$ is a promising solution, its application may have its limitations. There is no universal solution called "behavioural finance”. Participation is a function of financial literacy, perception of the base system and the architecture of pensions. Lunn [2012: 5-6] notes that, despite the observable effects, no explicit theoretical proof of the effectiveness and universality of the application of „behavioural” methods exists. Nevertheless, it seems intuitively true that at least some aspects of the applications are universal; especially in terms of long-term planning, confidence in the capital markets and understanding of financial concepts - for example compound interest or the difference between stocks and bonds.

Clearly, country specific social security influences, as well as wider socioeconomic market characteristic features, need to be taken into consideration or at least their presence and potential impact kept under control whilst analysing behavioural applications to enhance voluntary retirement savings. 
What is needed? A Pan-European or even Worldwide research programme, controlling the aforementioned variables. What is it for? First of all, BF is only just making its way into mainstream economics, and therefore international evidence could provide invaluable insights into what the inhibitors to participation are and whether there are indeed a myriad of behavioural and economic factors.

Comparative research could enable one to answer the questions on what are the common factors inhibiting participation. This may then be used by providers in their product development, but could also be used by policy makers to implement improvements enhancing coverage and participation. In view of the specific nature of $\mathrm{BF}$, where knowledge is gathered inductively, there is a requirement to obtain a confirmation of hypotheses by empirical research.

It cannot be said that if one effect or one aspect is effective in one environment, it will be as effective in another. To know how to enhance voluntary savings requires a number of empirical studies that examine the effectiveness of the application of behavioural finance.

This in turn requires raising interest and attention, and so this paper, hopefully, is a good starting point for such a venture.

\section{REFERENCES}

Alessie Rob J. M., van Rooij Maarten C. J., and Annamaria Lusardi, 2011, Financial Literacy, Retirement Preparation and Pension Expectations in the Netherlands, Working Paper No. 289, De Nederlandsche Bank NV: Amsterdam.

Antolin P., 2008, Coverage of Funded Pension Plans, OECD Working Papers on Insurance and Private Pensions No. 19, OECD publishing, (C) OECD. doi:10.1787/241142156207.

Antolin P., Payet S., Yermo J., 2012, Coverage of Private Pension Systems: Evidence and Policy Options, OECD Working Papers on Finance, Insurance and Private Pensions No. 20, OECD Publishing, http://dx.doi.org/10.1787/5k94d6gh2w6c-en.

Antolín P., Whitehouse E. R., 2009, Filling the Pension Gap: Coverage and Value of Voluntary Retirement Savings, OECD Social, Employment and Migration Working Papers No. 69, OECD Publishing. http://dx.doi.org/10.1787/227200770711.

Arkinstall V., 2008, Kiwisaver. NZ case study: choice and competition, In: International Federation of Pension Fund Administrators, (FIAP), 2008, Pensions for the future: Developing individually funded programs, Lima, Peru.

Baddeley M., 2013, Behavioural Economics and Finance, Routledge, New York and London.

Barr N., Diamond P., 2008, Reforming pensions: Principles and policy choices, New York and Oxford: OUP.

Bańbuła P., 2006, Oszczędności i wybór międzyokresowy - podejście behawioralne, Materiały i Studia, Zeszyt 208, Narodowy Bank Polski, Warszawa.

Benartzi S., Thaler Richard, 2013, Behavioral Economics and the Retirement Savings Crisis, Science Magazine 339, March 8.

Benartzi S., Thaler R., 2007, Heuristics and Biases in Retirement Savings Behavior, Journal of Economic Perspectives 21(3).

Bernartzi S., Thaler R., 2004, Save More Tomorrow: Using Behavioral Economics in Increase Employee Saving, Journal of Political Economy 112(1). 
Beshears John James J. Choi, Laibson David, Madrian Brigitte C., 2006a, The Importance of Default Options for Retirement Savings Outcomes: Evidence from the United States, NBER Working Paper No. 12009, January 2006, Revised March 2007, http://www.nber.org/papers/w12009.pdf.

Beshears John James J. Choi, Laibson David, Madrian Brigitte C., 2006b, Simplification and saving, NBER Working Paper No. 12659, http://www.nber.org/papers/w12659.pdf.

Beshears John James J. Choi, Laibson David, Madrian Brigitte C., Weller Brian, 2008, Public Policy and Saving for Retirement: The Autosave Features of the Pension Protection Act of 2006, http://www.aeaweb.org/annual_mtg_papers/2008/2008_265.pdf.

Blaich R., 2010, Occupational pensions in Germany Time for Action Aegon International http://www.aegonglobalpensions.com/Documents/aegon-global-pensions-com/Publications/ Research-papers/White-paper-Occupational-pensions-in-Germany-English.pdf.

Blake D., 2006, Pension Economics, Wiley, Chichester.

Börsch-Supan A., 2004, Mind the GAP: The Effectiveness of Incentives to Boost Retirement Saving in Europe, OECD Economic Studies No. 39, 2004/2, 111-144.

Brunhart N., 2008, Individual Financial Planning for Retirement: Empirical Insights from the Affluent Segment in Germany, Contributions to Economics Psychica - Verlag (Springer), Heidelberg.

Camerer C. F., Loewenstein G., Rabin M., 2004, Advances in Behavioural Economics, Russel Sage Foundation, NY Princetown University Press Princeton and Oxford.

Chybalski F., 2009, Barriers to Increased Effectiveness of Investment by Pension Funds in Poland, Discussion Paper PI 0910, Pensions Institute, http://www.pensions-institute.org/workingpapers/wp0910.pdf.

Chybalski F., 2011, The Choice of Open Pension Fund made by Citizens of Poland in the Years 2003-2009: The Analysis of the Criteria, Discussion paper PI 1102, Pensions Institute http://www.pensions-institute.org/workingpapers/wp1102.pdf.

Cousins M., 2005, European Welfare States. Comparative perspectives, Sage: London.

Crossley T. F., Emmerson C., Leicester C., 2012, Raising Household Saving, Institute For Fiscal Studies, London February.

Diamond P., Koszegi B., 2003, Quasi-Hyperbolic Discounting and Retirement, Journal of Public Economics 87(9-10), 1839-1872.

Disney R., 2007, Household savings rates and the design of public pension programmes Cross country evidence Centre for finance and credit markets, Working Paper 07/02 Notthingam.

EIOPA, 2013, Good practices on information provision for DC schemes. Enabling occupational DC scheme members to plan for retirement, BoS 13/010 European Insurance and Occupational Pension Authority Frankfurt Germany, https://eiopa.europa.eu/fileadmin/tx_dam/ files/publications/reports/Report_Good_Practices_Info_for_DC_schemes.pdf.

European Commission (EUC), 2010, Private pension schemes. Their role in adequate and sustainable pensions, Luxembourg: Publications Office of the European Union, http://ec.europa.eu/social/BlobServlet?docId=4853\&langId=en.

EUC, 2007, Pensions Schemes and Projection Models in EU-25 Member States, EFA-DG EUC Number 35.

EUC, 2012, Pension Adequacy in the European Union. 2010-2050, Report prepared jointly by the Directorate-General for Employment, Social Affairs and Inclusion of the European Commission and the Social Protection Committee. Luxembourg: Publications Office of the European Union, 2012 doi:10.2767/77325.

Esping-Andersen G., 1990, The three worlds of welfare capitalism, Polity Press: Cambridge UK.

Esping-Andersen G. (ed.), 2002, Why we need a new welfare state, Oxford University Press: New York.

Evans J., 2003, In two minds: Dual-process accounts of reasoning, Trends in Cognitive Sciences $7(10)$, October. 
Frederick S., Loewenstein G., O'Donoghue T., 2002, Time Discounting and Time Preference:

A Critical Review, Journal of Economic Literature 40(2) (Jun., 2002), 351-401.

Góra M., 2003, System emerytalny, Wydawnictwo ekonomiczne, Warszawa.

Greenwood J., 2012, Pensions and Wealth in Retirement, $2^{\text {nd }}$ edition, Financial Times Publishing,

Pearsons, London.

Hardcastle R., 2012, How can we incentivise pension saving? A behavioural perspective, DWP Working Paper No. 109, UK.

Hinz R., 2008, Voluntary retirement savings: Motivations incentives and design, In: International Federation of Pension Fund Administrators, (FIAP), 2008, Pensions for the future: Developing individually funded programs, Lima, Peru.

Holzmann R., Hinz R. (eds.), 2012, Matching Defined Contribution (MDC) Schemes: A Promising Pension Design to Enhance Coverage and Benefit Level?, Washington DC: World Bank.

http://web.worldbank.org/WBSITE/EXTERNAL/TOPICS/EXTSOCIALPROTECTION/EXTPEN SIONS/0,,contentMDK:22943207 menuPK:396295 pagePK:64020865 piPK:51164185 th eSitePK:396253 isCURL:Y,00.html.

Iwry J. Mark, John David C., 2009, Pursuing universal retirement security through automatic IRAs. Retirement Security Project Policy Brief No. 2009-3, http://www.brookings.edu/papers/2009/07_automatic_ira_iwry.aspx.

Kahneman D., Tversky A., 1979, Prospect Theory: An Analysis of Decision under Risk, Econometrica 47(2), March.

Kahneman D., 2012, Thinking, Fast and Slow Penguin Books, London, UK.

Kahneman D., Knetsch J. L., Thaler R. H., 1991, Anomalies: The Endowment Effect, Loss Aversion and Status Quo Bias, Journal of Economic perspectives 5(1), Winter, 193-206.

Kahneman D., Tversky, A., 1986, Rational Choice and the Framing of Decisions, The Journal of Business 59, S251-S278.

Kahneman D., Knetsch J. L., Thaler R. H., 2008, The Endowment Effect: Evidence of Losses Valued More than Gains, Handbook of Experimental Economics Results 1, 939-948.

Knoll Melissa A. Z., 2010, The Role of Behavioral Economics and Behavioral Decision Making in Americans' Retirement Savings Decisions, Social Security Bulletin 70, No. 4 US SSA.

Loewenstein G., Thaler R. H., 1989, Anomalies: Intertemporal Choice, Journal of Economic Perspectives 3(4), 181-93, http://faculty.chicagobooth.edu/richard.thaler/research/pdf/intertemporal\%20choice.pdf.

Lunn P., 2012, Behavioural Economics and Policymaking Learning from the Early Adopters, Economic and Social Review 43(3), Autumn, 423-449, http://www.esri.ie/UserFiles/publications/WP425/WP425.pdf.

Madrian B. C., 2012, Matching Contributions and Savings Outcomes A Behavioral Economics Perspective, National Bureau of Economic Research NBER Working Paper w18220, July, Cambridge MA USA.

Madrian B. C., Shea D. F., 2001, The Power of Suggestion: Inertia in 401(k) Participation and Savings Behavior, Quarterly Journal of Economics 116, Issue 4, 1149-1187.

Mikulec A., 2012, Porównanie prywatnie zarzqdzanych planów emerytalnych - ujęcie OECD, Wiadomości Ubezpieczeniowe, W-Wa PIU.

Mitchell O. S., Utkus S. P., 2004, Pension Design and Structure. New Lessons From Behavioral Finance, Oxford University Press, New York.

Organisation for Economic Co-operation and Development (OECD), 2012, OECD Pensions Outlook 2012, OECD Publishing, http://dx.doi.org/10.1787/9789264169401-en.

OECD, 2011, Pensions at a Glance 2011: Retirement-income Systems in OECD and G20 Countries, OECD Publishing, http://dx.doi.org/10.1787/pension_glance-2011-en.

OECD, 2008, Complementary pensions throughout the world. OECD/ISSA/IOPS, http://www.oecd-ilibrary.org/finance-and-investment/complementary-and-private-pensionsthroughout-the-world-2008_9789264048829-en 
OECD, 2007, Policy Brief: Closing the pensions gap: the role of private pensions, http://www.oecd.org/insurance/public-pensions/39524851.pdf.

Polska Izba Ubezpieczeń PIU, 2010, Konferencja III filar - recepta na wyższa emeryturę, Dokumentacja Konferencji, Warszawa, Maj, http://www.piu.org.pl/public/upload/ibrowser/Emerytalne-1n.pdf.

Pieńkowska-Kamieniecka S., Ostrowska-Dankiewicz A., 2013, Dopłaty do dobrowolnych oszczędności emerytalnych - ocena skuteczności rozwiazań na przykładzie Niemiec i Nowej Zelandii, Wiadomości Ubezpieczeniowe 3, PIU, Warszawa.

Save More Tomorrow Act 2012, http://www.govtrack.us/congress/bills/112/s3175\#summary/libraryofcongress.

Shefrin H. M., Thaler R. H., 1988, The Behavioral Life-Cycle Hypothesis, Economic Inquiry 26(4), 609-643.

Shefrin H. M., Thaler R. H., 1981, An Economic Theory of Self-Control, Journal of Political Economy 89(2), April, University of Chicago Press, 392-406.

Sieczkowski W., 2014, Reforma systemu emerytalnego $w$ Wielkiej Brytanii, Wiadomości Ubezpieczeniowe 2, PIU, Warszawa.

Szumlicz T., 2005, Ubezpieczenie społeczne. Teoria dla praktyki, Oficyna Wydawnicza Branta, Bydgoszcz.

Stanko D., 2010, Transfery czlonków kapitalowych funduszy emerytalnych na swiecie i w Polsce. Analiza racjonalnosci decyzji czlonków OFE [Transfers of funded pension funds' members in the world and Poland. An analysis of rationality of choices of OFEs' members], Rozprawy Ubezpieczeniowe 8(1), 7-36.

Tapia W., Yermo J., 2007, Implications of Behavioural Economics for Mandatory Individual Account Pension Systems, OECD Working Papers on Insurance and Private Pensions No. 11, OECD Publishing, doi:10.1787/103002825851.

Thaler R. H., 1999, Mental Accounting Matters, Journal of Behavioral Decision Making 12(3), 183-206.

Thaler R. H., 2000, Quasi Rational Economics, New York Russell Sage Foundation.

Thaler R. H., 1990, Anomalies: Saving, Fungibility and Mental Accounts, Journal of Economic Perspectives 4(1), Winter, 193-205.

Thaler R. H., 1981, Some Emprirical Evidence on Dynamic Inconsistency, Economic Letters 8, 201-207.

Turner J., 1997, Retirement income systems for different economic, demographic and political environments, OECD Working Paper Ageing Working Papers 3.8, OECD: .

Wojciech Sieczkowski

\section{ZASTOSOWANIE FINANSÓW BEHAWIORALNYCH DO ZWIĘKSZANIA DOBROWOLNYCH OSZCZĘDNOŚCI EMERYTALNYCH - CZY ROZWIĄZANIA SĄ UNIWERSALNE NA CAŁYM ŚWIECIE?}

Finanse behawioralne wydają się być obiecującym rozwiązaniem służącym do poprawy poziomu dobrowolnych oszczędności emerytalnych i znajdują coraz szersze uznanie na świecie. Niemniej jednak, wydają się istnieć pewne ograniczenia co do uniwersalności zastosowania tych rozwiązań. Artykuł stanowi przegląd dostępnej literatury w zakresie oszczędzania długoterminowego, a następnie analizuje wspomniane ograniczenia, po pierwsze poprzez wskazanie użytych założeń metodologicznych, które mogą wpływać na wyciągane wnioski, a następnie zaproponowany jest zarys zbioru zmiennych wpływających na przenoszalność tych wniosków

Słowa kluczowe: finanse behawioralne, dobrowolne oszczędności emerytalne, reformy emerytalne, wielostopniowe systemy emerytalne. 